\title{
Reproductive Seasonality of Corriedale Rams under Extensive Rearing Conditions
}

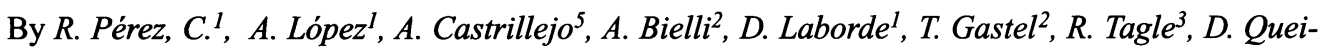 \\ rolo $^{1}$, J. Franco ${ }^{4}$, M. Forsberg ${ }^{5}$ and H. Rodríguez-Martínez ${ }^{6}$
}

Departments of ${ }^{1}$ Animal Anatomy \& Physiology and ${ }^{4}$ Statistics, Faculty of Agriculture, Departments of ${ }^{2}$ Histology and Embryology and ${ }^{3}$ Nuclear Techniques, Faculty of Veterinary Medicine, Uruguay; ${ }^{5}$ Private Veterinary Clinic \& Depts of Clinical Chemistry and Obstetrics and Gynaecology ${ }^{6}$, Faculty of Veterinary Medicine, Swedish University of Agricultural Sciences, Uppsala, Sweden.

\begin{abstract}
Pérez R., A. López, A. Castrillejo, A. Bielli, D. Laborde, T. Gastel, R. Tagle, D. Queirolo, J. Franco, M. Forsberg and H. Rodqíguez-Martínez: Reproductive seasonality of corriedale rams under extensive rearing conditions. Acta vet. scand. 1997, 38, 109-117. - The objective of the present study was to describe seasonal changes in scrotal circumference (SC), live weight (LW), sperm morphology and plasma levels of testosterone ( $\mathrm{T})$ and thyroxine $\left(\mathrm{T}_{4}\right)$ in young Corriedale rams reared under extensive conditions typical for the southern Latin American region. A total of 31 Corriedale rams, 11 months of age and with a LW of $36 \pm 1.1 \mathrm{~kg}$ and (SC) of $23.0 \pm 0.5 \mathrm{~cm}$ at the beginning of the experiment (September) were kept on natural pastures. At monthly intervals LW was recorded, animals were clinically examined, and SC was measured. None of the animals were used for breeding. Fifteen animals were randomly selected and bled once a month from January to December and plasma concentrations of $T$ and $\mathrm{T}_{4}$ were determined. In addition, one semen sample was collected by electroejaculation and morphological studies were performed. The mean individual LW increase was 18 $\mathrm{kg}(50 \%$ of the initial LW) during the experiment $(\mathrm{p}<0.01)$. LW decreased in autumn, with the nadir in late autumn. SC reached mean maximum levels in late summer (31.1 $\pm 0.4 \mathrm{~cm}, \mathrm{p}<0.01)$, then decreased until the beginning of winter $(26.3 \pm 0.4 \mathrm{~cm}, \mathrm{p}<0.01)$ and remained low until early spring $(27.5 \pm 0.5 \mathrm{~cm}, \mathrm{p}>0.05)$ to increase again between mid-spring and the end of the experimental period the following summer $(30.7 \pm 0.5 \mathrm{~cm}$, $\mathrm{p}<0.01$ ). The mean SC in winter was $16 \%$ lower than that in late summer. Semen could be collected from the rams throughout the experiment. Frequencies of sperm head, midpiece and total abnormalities showed monthly variation $(\mathrm{p}<0.05)$, but tail abnormalities were not affected by month. Low abnormalities were found in autumn $(9.4 \% \pm 2.2 \%)$. $\mathrm{T}$ was high during autumn $(\mathrm{p}<0.01)$. Minimal T4 concentrations were observed during late summer and early autumn $(p<0.01)$ when $T$ levels were high. Maximum T4 concentrations were registered in late autumn $(\mathrm{p}<0.01)$, when $\mathrm{SC}$ was decreasing; in midspring $(p<0.01)$ one month after shearing and in early summer $(p<0.01)$. The results suggest that Corriedale rams under Uruguayan extensive management systems show a reproductive seasonality that, in general terms, coincides with photoperiodic variations.
\end{abstract}

\section{Introduction}

Most mammals show a seasonal pattern in their reproductive activity that is shaped by seasonal changes in their habitats (Bronson 1988). Male sheep of practically all breeds living above $40^{\circ}$

1 Current address: Dept.of Clinical Chemistry, Swedish University of Agricultural Sciences, P.O. Box 7038, S-750

07 Uppsala, Sweden. latitude in the Northern Hemisphere display seasonal variations in testicular volume and daily sperm production (Pelletier et al. 1988). The reproductive activity of rams is influenced 
by season (Lincoln \& Short 1980), with photoperiod being the main environmental signal timing the reproductive cycle (Alberio et al. $1979 \mathrm{a}, \mathrm{b}$ and c). However, the light/dark cycle is not the only cue (Martin et al. 1990). Under extensive rearing conditions, food supply may have more influence than photoperiod (Masters \& Fels 1984). Social interactions may also influence ram reproductive activity (Illius et al. 1976, Sanford \& Yarney 1983).

Most of the Corriedale world stock is raised under extensive conditions in the temperate to subtropical southern Latin American region. The main breeding system is based on yearround grazing, with sheep and cattle competing for the same forage. Gastel et al. (1995) provided evidence that seasonal changes occur in the testicular morphology of extensively reared Corriedale rams. With better knowledge of ram reproductive physiology more accurate andrological evaluations could be conducted which would improve reproductive efficiency and enhance breeding schemes and the rate of genetic gain.

The objective of the present study was to describe seasonal changes in scrotal circumference, live weight, sperm morphology and plasma levels of testosterone and thyroxine in young Corriedale rams reared under extensive conditions typical for the southern Latin American region.

\section{Materials and Methods}

Location, animals and experimental design: The experiment was carried out from September 1990 to December 1991 on a farm located in Molles, Durazno Uruguay $\left(32^{\circ} \mathrm{SL}\right)$ under extensive rearing conditions typical for the country. Daylight varies from about $14 \mathrm{~h} 30 \mathrm{~min}$ in December to about $9 \mathrm{~h} 40 \mathrm{~min}$ in June. The average temperatures during the experiment varied from $10.5^{\circ} \mathrm{C}$ (June) to $26^{\circ} \mathrm{C}$ (January). $\mathrm{Al}$ - though it rained during all months of the experiment, there were great variations in rainfall. In September 1990, and in February, March, April, August, September and November of 1991, rainfall was less than $100 \mathrm{~mm}$.

The basaltic soils of the region have a herbaceous vegetation dominated in summer by perennial Gramineae (Paspalum, Axonopus, Bothriocloa). The availability of forage in winter is low and of varying quality (Gramineae, Stipa, Poa, Leguminosae, Adesmia bicolor, Trifolium polymorfo, non-Gramineae, Oxalis, Ciperaceas, Eringium; Formoso \& Castrillejo 1989). A total of 31 Corriedale rams, 11 months of age and with a live weight of $36 \pm 1.1 \mathrm{~kg}$ at the beginning of the experiment, were kept on natural pastures and managed the same way throughout the work. The animals were randomly selected from a breeding flock which grazed together with beef cattle in the neighboring paddocks of the farm. At monthly intervals body weight was recorded early in the morning. Animals were clinically examined, and scrotal circumference (SC) was measured with a flexible tape at the widest scrotal diameter. The mean SC was 23.0 $\pm 0.5 \mathrm{~cm}$ at the beginning of the trial. Animals were sheared in September and their fleece weight registered. Live weight (LW) was estimated throughout the experiment, as described by Gastel et al. (1995). None of the animals was used for breeding.

Fifteen animals were randomly selected, bled and electroejaculated once a month from January to December. Blood samples were withdrawn into heparinized tubes by jugular venipuncture from 9:30 to 11:00 a.m. and immediately placed on ice. The blood plasma harvested after centrifugation was stored at $-20^{\circ} \mathrm{C}$, within $10-12 \mathrm{~h}$ after bleeding, until analyzed for contents of testosterone ( $\mathrm{T}$ ) and thyroxine $\left(\mathrm{T}_{4}\right)$. Semen smears were immediately prepared, and another aliquot of the semen sample was fixed with buffered formol saline solu- 
tion. In the laboratory the smears were stained with haematoxylin-eosin (Schoenfeld et al. 1981) and examined in a light microscope where sperm head abnormalities were recorded. Abnormalities of sperm mid-pieces and tails were estimated with a phase-contrast microscope (Leitz Dialux 20) onto wet-smears. On every slide, 200 spermatozoa were counted. All examinations were performed by the same operator.

\section{Hormone assays}

$\mathrm{T}$ and $\mathrm{T}_{4}$ contents of plasma samples were determined using commercial RIA kits (Coat-ACount testosterone and thyroxine; Diagnostic Products Corporation, Los Angeles, CA, U.S.A.). The procedures were validated by means of parallelism tests. The similarity between observed and expected values was $95 \%, 94 \%$ and $87 \%$ for $\mathrm{T}$ and $95 \%, 94 \%$ and $92 \%$ for T4 using 1/2,1/4 and 1/8 dilutions of ovine plasma, respectively. The intra-assay and inter-assay coefficients of variation were $6.5 \%$ and $9.3 \%$ for $\mathrm{T}$, and $4.5 \%$ and $12 \%$ for $\mathrm{T} 4$. The limit of detection (defined as the intercept of maximal binding - 2SD) was $0.3 \mathrm{nmol} / 1$ for $\mathrm{T}$ and $3.9 \mathrm{nmol} / 1$ for $\mathrm{T}_{4}$. All samples were processed in duplicate. Standard curves and concentrations in unknown samples were calculated using the Wiacalc program (LKB-Wallac, Turku, Finland).

\section{Statistical analysis}

The collected data were analyzed according to the following linear model: $\mathrm{y}_{\mathrm{ijk}}=\mathrm{u}+\mathrm{C}_{\mathrm{i}}+\mathrm{M}_{\mathrm{j}}+$ $e_{i j k}$, where: $y_{i j k}=$ dependent variable, $u=$ general mean, $C_{i}=$ effect of the ith ram, $M_{j}=$ effect of the jth month, $\mathrm{e}_{\mathrm{ijk}}=$ random error. The LSD test was used to separate means. Regression analysis was performed between $\mathrm{LW}$ and SC, and correlations were studied between SC and T. All $\mathrm{p}<0.05$ were considered significant. Results are expressed as mean \pm s.e.m.

\section{Results}

During the first 6 months of the experiment, 5 animals were discarded after clinical exams. The reasons were spermatic granuloma (2), orchitis (1) and small testes (2). Data on these animals were, consequently, not used in the analyses. In December of 1991, one ram was suspected of having spermatic granuloma; thus data from this ram and month were also withdrawn from the analyses.
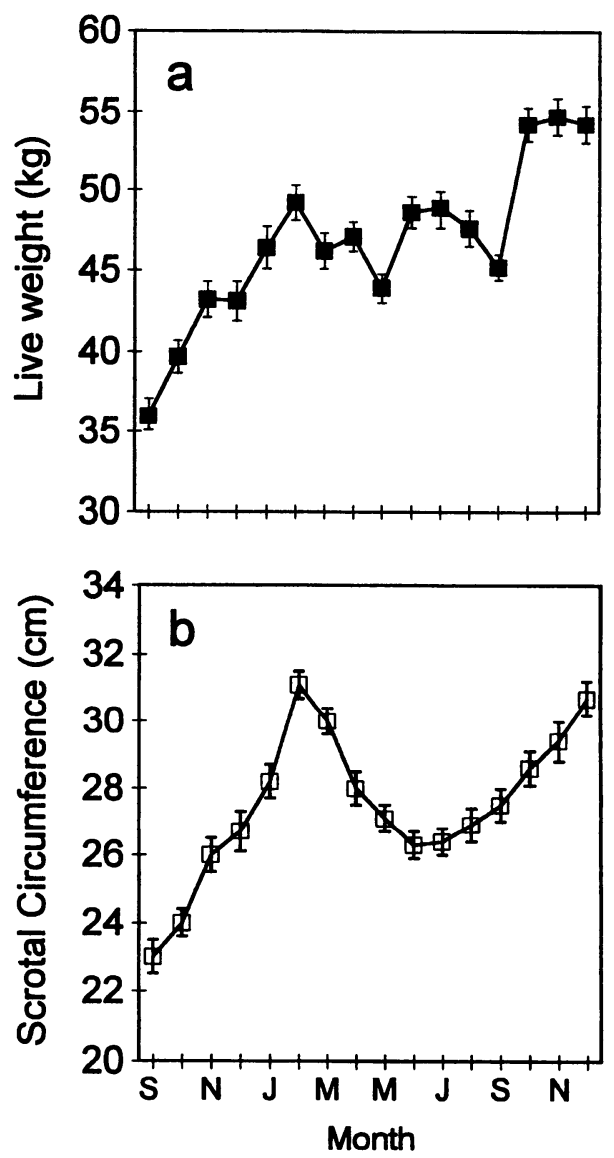

Figures 1 a and 1 b. Live weight (a) and scrotal circumference (b) in 26 Corriedale rams between 11 and 26 months of age (September 1990-December 1991) (means \pm sem). 
Table 1. Sperm abnormalities (\%) in the semen of young Corriedale rams during the seasons studied (mean \pm s.e.m., $\mathrm{n}=15$ ).

\begin{tabular}{lrrrc}
\hline SEASON & \multicolumn{1}{c}{ HEAD } & MID-PIECE & \multicolumn{1}{c}{ TAIL } & TOTAL \\
\hline Spring 90 & $8.0^{\mathrm{a}} \pm 1.4$ & $0.8^{\mathrm{a}} \pm 0.2$ & $6.0^{\mathrm{a}} \pm 1.4$ & $14.8^{\mathrm{a}} \pm 2.0$ \\
Summer & $5.0^{\mathrm{ab}} \pm 1.3$ & $1.0^{\mathrm{a}} \pm 0.4$ & $8.0^{\mathrm{a}} \pm 3.2$ & $14.0^{\mathrm{a}} \pm 4.3$ \\
Autumn & $4.0^{\mathrm{b}} \pm 1,0$ & $0.4^{\mathrm{b}} \pm 0.1$ & $5.0^{\mathrm{a}} \pm 1.3$ & $9.4^{\mathrm{b}} \pm 2.2$ \\
Winter & $3.0^{\mathrm{b}} \pm 1,0$ & $0.6 \mathrm{a}^{\mathrm{b}} \pm 0.2$ & $6.0^{\mathrm{a}} \pm 1.8$ & $9.6^{\mathrm{ab}} \pm 2.5$ \\
Spring 91 & $6.0^{\mathrm{ab}} \pm 1,9$ & $0.4 \mathrm{a}^{\mathrm{b}} \pm 0.3$ & $6.0^{\mathrm{a}} \pm 1.7$ & $12.4^{\mathrm{a}} \pm 3.3$ \\
\hline
\end{tabular}

Means followed by different letters within a column differ significantly $(\mathrm{p}<0.05)$

An increase in sexual activity of the rams during the breeding season was observed. Intermale aggression and homosexual mounts were frequent during this period. Rams spent long hours wandering along the wire fences during this period. As stated above, a breeding flock grazed in the neighboring paddocks.

The results of LW and SC are presented in Figs. $1 \mathrm{a}$ and $1 \mathrm{~b}$. The mean individual weight increase was $18 \mathrm{~kg}$ ( $50 \%$ of the initial LW) during the experiment $(\mathrm{p}<0.01)$. LW decreased in autumn, with the nadir in late autumn (May). Another decrease was observed in spring (September), coinciding with the shearing of the animals. Scrotal circumference reached mean maximum levels in late summer (February: $31.1 \pm 0.4 \mathrm{~cm}$, $\mathrm{p}<0.01$ ), then decreased until the beginning of winter (June: $26.3 \pm 0.4 \mathrm{~cm}, \mathrm{p}<0.01$ ) and remained low until early spring (September: 27.5 $\pm 0.5 \mathrm{~cm}, \mathrm{p}>0.05)$ to increase again between mid-spring (October) and the end of the experimental period $(30.7 \pm 0.5 \mathrm{~cm}, \mathrm{p}<0.01)$. The mean SC in winter (June) was $16 \%$ lower than that in late summer (February), but differences in SC diminution between rams were observed: One ram showed a $9 \%$ decrease, 16 a $10 \%$ $20 \%$ decrease and nine a $20 \%-30 \%$ decrease. Both LW and SC were significantly influenced by month $(\mathrm{p}<0.0001)$ and ram $(\mathrm{p}<0.0001)$. Although a significant $(\mathrm{p}<0.0001)$ interaction between LW and SC was found, this relationship varied between months in either linear or quadratic analytical models. Changes in LW could explain more than $50 \%\left(\mathrm{r}^{2}: 0.51-0.67\right)$ of the variations in $\mathrm{SC}$ between the first spring and summer (September 1990 to January 1991). Thereafter the regression coefficients gradually decreased from the first $\left(0.33 ; \mathrm{r}^{2}=\right.$ $0.67)$ to second $\left(0.17 ; \mathrm{r}^{2}=0.17\right)$ summer (December 1990 to December 1991). It was only in September 1991 that the regression was nonsignificant $(\mathrm{p}>0.05)$.

Semen could be collected from the rams throughout the experiment. The results of the morphological assessment are shown in Table 1. Frequencies of sperm heads, midpieces and total abnormalities showed monthly and seasonal variation $(\mathrm{p}<0.05)$, but tail abnormalities were not affected by month or by season. However, all variables showed a strong ram effect $(p<0.0001)$. Regardless of season, tailless heads and sperm heads narrow at the base were the main sperm head abnormalities seen. Proximal droplets, simple bent tails and tails coiled around the head were the main mid-piece and tail abnormalities recorded throughout the experimental period.

Testosterone and $\mathrm{T}_{4}$ concentrations during the experimental period are shown in Figs. $2 \mathrm{a}$ and $2 b$. The concentration of $T$ was affected by month $(\mathrm{p}<0.0001)$ but not by ram $(\mathrm{p}>0.05)$. $\mathrm{T}$ was high during autumn (March: $19.7 \pm 3.7$ $\mathrm{nmol} / \mathrm{l}, \mathrm{p}<0.01$ and April: $12.0 \pm 2.8 \mathrm{nmol} / 1$, $\mathrm{p}<0.01$ ). The highest concentration of $T$ was re- 

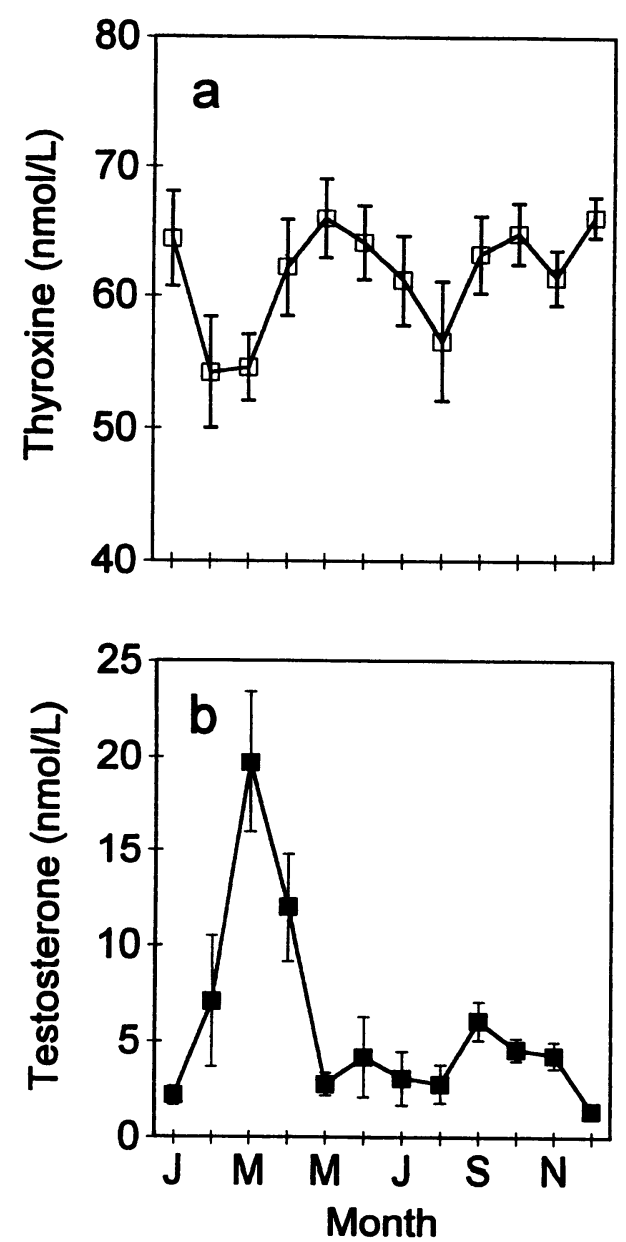

Figures 2 a and 2 b. Plasma concentrations of (a) testosterone and (b) thyroxine in 15 Corriedale rams, between 15 and 26 months of age (January-December 1991) (means \pm sem).

corded in March (when $80 \%$ of the animals had their highest $\mathrm{T}$ ), one month later than SC values reached their maximum. There was a significant correlation between $\mathrm{SC}$ and $\mathrm{T}(\mathrm{r}=0.26$, $\mathrm{p}<0.01)$. The $\mathrm{T}_{4}$ concentration was affected by month $(\mathrm{p}<0.03)$ and ram $(\mathrm{p}<0.001)$. When the lowest and highest concentrations of $\mathrm{T}_{4}$ were compared, minimal $\mathrm{T}_{4}$ concentrations were observed during late summer and early autumn (February: $54.2 \pm 4.2 \mathrm{nmol} / 1, \mathrm{p}<0.01$ and March: $54.6 \pm 2.5 \mathrm{p}<0.01$ ) when $\mathrm{T}$ levels were high. Maximum $\mathrm{T}_{4}$ concentrations were registered in late autumn (May: $66.0 \pm 3.1 \mathrm{nmol} / \mathrm{l}$, $\mathrm{p}<0.01$ ), when SC was decreasing; in midspring (October: $64.1 \pm 2,4 \mathrm{nmol} / \mathrm{l}, \mathrm{p}<0.01$ ), one month after shearing, and in early summer (December: $66.1 \pm 1.6 \mathrm{nmol} / \mathrm{l}, \mathrm{p}<0.01$ ).

\section{Discussion}

The results show that spermatogenic activity was present all year round in young Corriedale rams which is in agreement with observations reported by Gastel et al. (1995) in the same flock.

LW and SC tended to rise during the experimental period. However, the relationship between $\mathrm{LW}$ and $\mathrm{SC}$ varied. In the statistical model, more than $50 \%$ of the variation in SC during the first spring and summer were explained by changes in LW. By the following spring this figure had decreased to around $20 \%$. This difference might be explained by the difference in age of the animals between the beginning and end of experimental period ( $\mathrm{Al}$ meida et al. 1981). The animals were evaluated from 11 to 26 months of age under extensive pastoral conditions. Rams were still growing during this period. Live weight at 24 months of age was consistent with previous reports for the same breed, age and foraging conditions (Rodríguez 1990).

The loss of LW registered in autumn could have been due to a number of factors. One of them is a reduction in feeding time associated with increased sexual activity. It could also have been a consequence of a decrease in the availability of forage due to overripening of the summer pastures ( $90 \%$ of total pasture available). On the other hand, the weight gain recorded in winter was probably due to the animals feeding on 
actively growing winter grasses and to the fact that bovines sharing the foraging area with the sheep consumed the dry remnants of the summer grasses (Formoso \& Castrillejo 1989). There is some experimental evidence that forage availability has a strong effect on weight gain in cattle but not in sheep, probably because sheep are highly selective grazers (Formoso \& Castrillejo 1989; Formoso \& Gaggero 1990).

The LW loss in the spring (September 1991) was probably due to the stress and diminished grazing time resulting from shearing, since measurements were performed shortly thereafter. The increase in LW observed during the following month was probably a consequence of the augmented voluntary feed intake that typically occurs after shearing (Wodzicka-Tomaszewska 1963). Increased $T_{4}$ levels were observed on this occasion in all rams, suggesting that the metabolic rate was higher during this period at the same time as forage quality and availability increased in spring (Formoso \& Castrillejo 1989).

Seasonal variations in sperm abnormalities showed a tendency similar to those reported in other breeds of sheep (Cupps et al. 1960, Colas 1980, Mickelsen et al. 1981). One reason for the increase in sperm abnormalities in summer could be the influence of high ambient temperature (Rathore \& Yates 1967). The increased amount of immature spermatozoa (proximal droplets) might have been due to the increased sexual activity shown by the rams during the period from late summer to mid-autumn.

In the present study plasma levels of $T$ were high at the beginning and middle of autumn. The high variation of $\mathrm{T}$ in this period was most certainly due to sampling methodology. Rams were bled only once, and it is well known that testosterone secretion varies in a pulsatile way (Ortavant et al. 1982). Testosterone reached maximal levels one month after the testes had attained their maximum volume, which has also been reported to occur in other breeds of sheep (Lincoln et al. 1990). The conspicuous fall in plasma $T$ in late autumn coincided with the beginning of the minimum-SC period. A similar pattern was reported in Merino rams kept in Australian grasslands (Bremner et al. 1984). The influence of photoperiod on sheep reproductive seasonality is well documented (Legan $\&$ Karsch 1980, Alberio et al. 1979, a, b and c). Scrotal circumference began to increase in spring, one to 2 months before the summer solstice, as reported in other ovine breeds (Lincoln et al. 1990). Maximal SC was observed 2 months after the summer solstice when daylength was decreasing. Many reports show that maximum testicular volume is reached during periods of decreasing daylength (Mickelsen et al. 1981, Lincoln et al. 1990). In the present investigation, regression of the testes began relatively sooner than for other breeds of sheep (Lincoln \& Short 1980), but our data are in accordance with those obtained in Corriedale ( $\mathrm{Al}$ meida \& Alberio 1981) and Merino (Gibbons et al. 1991) rams in Argentina.

Minimal levels of $\mathrm{T}_{4}$ were registered during the period of maximum $\mathrm{SC}$ and $\mathrm{T}$ levels in late summer - early autumn. Conversely, a $\mathrm{T}_{4}$ peak was observed in late autumn when $\mathrm{SC}$ and $\mathrm{T}$ fell abruptly. A negative association between $\mathrm{T}$ and $\mathrm{T}_{4}$ has been reported in other seasonal mammals like the fox (Vulpes vulpes, Forsberg \& Madej 1990; Maurel \& Boissin 1981) and mink (Mustela vison, Jacket et al. 1986). In Suffolk ewes under a natural photoperiod Webster et al. (1991) observed an annual cycle in $\mathrm{T}_{4}$, with the lowest values occurring in spring and summer and a peak in late autumn and winter.

It has been postulated that seasonal reproduction in sheep is generated by endogenous signals and timed by annual changes in photoperiod (Karsch \& Wayne 1988) and that hormones of the thyroid gland are involved in the mecha- 
nism ending the breeding season in ewes ( $\mathrm{Web}$ ster et al. 1991, Moetner et al. 1991) and rams (Parkinson \& Follet 1994). Thyroxine might also be the signal ending the reproductive season in other species (Shi \& Barrel 1992). In the fox, exogenous melatonin influenced testes volume, $\mathrm{T}$ and $\mathrm{T}_{4}$ secretion but did not change the negative association between the hormones (Forsberg \& Madej 1990). The relationship between melatonin and thyroxine is not clear. Thyroidectomized Suffolk ewes exposed to an abrupt change in photoperiod displayed normal melatonin secretion, but LH secretion was affected (Dalh et al. 1994). Karsch et al. (1995), in a recent review, proposed that thyroid hormones must be present to permit the seasonal changes in neuroendocrine activity that lead to reduction of GnRH secretion and transition from the breeding season to the anoestrus period in the ewe.

In conclusion, Corriedale rams under extensive management systems showed a reproductive seasonality that, in general terms, coincided with photoperiodic variations related to reproductive seasonality in other breeds of sheep. Maximal reproductive activity, as evidenced by a large SC, high T plasma levels and the presence of low sperm abnormalities in semen, was recorded in autumn. However, the present study can not rule out that nutritional factors could influence the seasonal changes in SC. Further studies are needed to elucidate the roles of nutrition and photoperiod in the seasonal breeding of Corriedale rams.

\section{Acknowledgements}

The authors are indebted to the working staff at "El Recreo". Without their help this study would not have been possible. Financial support was received by IFS (Grant B/1917-1). Dr. Raquel Pérez Clariget is holder of a scholarship from CSIC of the Universidad de la República Oriental del Uruguay which supports her stay in Sweden.

\section{References}

Alberio R, Colas G, Guerin Y: Fotoperiodismo y evolución sexual en el cordero I. Desarrollo testicular y comportamiento sexual. Prod. Anim. (Bs. As.). 1979, 6, 133-141.

Alberio R, Colas G, Guerin Y: Fotoperiodismo y evolución sexual en el cordero II. Producción espermática. Prod. Anim. (Bs. As.). 1979, 6, 142-154.

Alberio R. Pelletier J, Terqui M, Ravault P: Fotoperiodismo y evolución sexual en el cordero III. Equilibrio endócrino. Prod. Anim.(Bs. As.). 1979, 6, 142-154.

Almeida G, Alberio R, Murtagh JJ: Estudio de las variaciones de la actividad reproductiva en un grupo de carneros Corriedale a lo largo de un año. Prod. Anim. (Bs. As.). 1981, 8, 343-354.

Bremner WJ, Cumming IA, Winfield C, de Kretser $D M$, Galloway D: A study of the reproductive performance of mature Romney and Merino rams throughout the year. In: Linsay DR, Pearce DT (eds): Reproduction in Sheep Cambridge University Press. 1984, pp. 16-19.

Bronson FH: Mammalian reproductive strategies: genes, photoperiod and latitude. Reprod. Nutr. Dévelop. 1988, 28 (2B), 335-347.

Colas $G$ : Variations saisonnières de la qualité du sperma chez le bélier Ile-de-France. Reprod. Nutr. Dévelop. 1980, 20, 1789-1799.

Cupps PT, McGowan B, Rahlmann DF, Reddon AR, Weir WC: Seasonal changes in the semen of rams. J. Anim. Sci. 1960, 19, 208-213.

Dahl GE, Evans NP, Moetner SM Karsch FJ: The thyroid gland is required for reproductive neuroendocrine responses to photoperiod in the ewe. Endocrinology 1994, 135, 10-15.

Formoso D, Castrillejo A: Selectividad en sistemas intensivos de pastoreo. Produc. Ovina. 1989, 2, $1-9$.

Formoso D, Gaggero C: Efecto del sistema de pastoreo y la relación ovino/vacuno sobre la producción de forraje y la vegetación del campo nativo. In: Proc. II Seminario Nacional de Campo Natural, Tacuarembó, Uruguay. 1990, pp. 299310.

Forsberg M, Madej A: Effects of melatonin implants on plasma concentrations of testosterone, thyroxine and prolactin in the male silver fox (Vulpes vulpes). J. Reprod. Fert. 1990, 89, 351-358.

Gastel MT, Bielli A, Pérez R, López A, Castrillejo A, Tagle R, Franco J, Laborde D, Forsberg M, Rodríguez-Martínez H: Seasonal variations in 
testicular morphology in uruguayan Corriedale rams. Anim. Reprod. Sci. 1995, 40, 59-75.

Gibbons AE, Willems P, García Vinent JC, González $R$ : Variación estacional de la actividad reproductiva del carnero Merino Australiano en la Patagonia. Rev. Arg. Prod. Anim. 1991, 11, 449-455.

Illius AW, Haynes NB, Lamming GE: Effects of ewe proximity on peripheral plasma testosterone levels and behaviour in the ram. J. Reprod. Fert. 1976, 48, 25-32.

Jacquet JM, Coutant C, Maurel D, Boissin-Agasse L, Boissin J: Influence de la thyroïdectomie sur les variations au cours du printemps et de l'eté de l'activité testiculaire et de la prolactinémie chez le Vison. C.R. Acad. Sci. Paris. 1986, 303, 367370.

Karsch FJ, Dahl GE, Hachigian TM, Thrun LA: Involvement of thyroid hormones in seasonal reproduction. J. Reprod. Fert., Suppl. 1995, 49, 409-422.

Karsch FJ, Wayne NL: Interplay of endogenous rhythms and environmental cues in organizing the seasonal reproductive cycle of the ewe. 11th Int. Congr. Anim. Reprod., July, 1988, Dublin, Ireland. 1988, pp. 220-227.

Legan SJ, Karsch FJ: Photoperiodic control of seasonal breeding in ewes: modulation of the feedback action of estradiol. Biol. Reprod. 1980, 29, 316-325.

Lincoln GA, Lincoln CE, McNeilly AS: Seasonal cycles in the blood plasma concentration of FSH, inhibin and testosterone size in rams of wild, feral and domesticated breeds of sheep. J. Reprod. Fert. 1990, 88, 623-633.

Lincoln $G A$, Short $R V$ : Seasonal breeding: Nature's contraceptive. Recent. Prog. Horm. Res. 1980, $36,1-52$.

Martin GB, Ford JR, Purvis IW: Environmental and genetic factors affecting reproductive activity in the Merino ram. In: Reproductive Physiology of Merino Sheep - Concepts and Consequences. The Univ. of Western Australia, Perth. 1990, pp.109-129.

Masters G, Fels HE: Seasonal changes in the testicular size of grazing rams. Anim. Prod. in Aust. 1984, 15, 444-447.

Maurel D, Boissin J: Plasma thyroxine and testosterone levels in the red fox (Vulpes vulpes L.) during the annual cycle. Gen. Comp. Endocrinol. 1981, 43, 402-404.

Mickelsen WD, Paisley LG, Dahmen JJ: The effects of season on the scrotal circumference and sperm motility and morphology in rams. Theriogenology 1981, 16, 45-51.

Moetner SM, Woodfill CJI, Karsch FJ: Role of the thyroid gland in seasonal reproduction: thyroidectomy blocks seasonal suppression of reproductive neuroendocrine activity in ewes. Endocrinology. 1991, 128, 1337-1344

Ortavant R, Daveau A, Garnier DH, Pelletier J, de Reviers $M M$, Terqui $M$ : Diurnal variation in release of $\mathrm{LH}$ and testosterone in the ram. J. Reprod. Fert. 1982, 64, 347-353.

Parkinson TJ, Follet BK: Effect of thyroidectomy upon seasonality in rams. J. Reprod. Fert. 1994, 101, 51-58.

Pelletier J, Chemineau P, Delgadillo JA: Seasonality of sexual activity and its photoperiodic control in the adult ram and he-goat. Proc. 11th Int. Congr. Anim. Reprod., July, 1988, Dublin, Ireland. 1988, pp. 211-219

Rathore AK, Yeates NIM: Morphological changes in ram spermatozoa due to heat stress. Vet. Rec. 1967, 81, 343-345.

Rodríguez AM: Importancia de la recría en los sistemas de producción ovina. In: Proc. III Seminario Técnico de Producción Ovina, SUL, Paysandú, Uruguay. 1990, 129-145

Sanford LM, Yarney TA: Circannual changes in serum levels of pituitary hormones and testosterone and in testis size of sexually active inactive adults rams. Can. J. Anim Sci. 1983, 63, 811-821.

Schoenfeld C, Amelar RD, Dublin L, Amelar S: A new staining technique for the rapid determination of the morphologic characteristics of sperm. Fertil. and Steril. 1981, 36, 408-409.

Shi $Z D$, Barrel $G K$ : Requirement of thyroid function for the expression of seasonal reproductive and related changes in red deer (Cervus elaphus) stags. J. Reprod. Fert. 1992, 94, 251-259.

Webster JR, Moenter SM, Woodfill CJI, Karsch FJ: Role of the thyroid gland in seasonal reproduction. II. Thyroxine allows a season-specific suppression of gonadotropin secretion in sheep. Endocrinology. 1991, 129, 176-183.

Wodzicka-Tomaszewska $M$ : Effect of shearing on sheep. N.Z.J. Agric. 1963, 107, 203-205. 


\section{Sammanfattning \\ Säsongsmässiga förändringar $i$ fortplantningsför- mågan hos baggar av rasen Corriedale på extensivt bete.}

En studie genomfördes för att beskriva de säsongsmässiga förändringarna $\mathrm{i}$ testikelomfång, levande vikt, spermiemorfologi och plasmakoncentrationer av testosterone och tyroxin hos unga baggar av rasen Corriedale uppfödda under extensiva förhållanden typiska för södra Latinamerika. Totalt 31 Corridalelamm, 11 månader gamla med en levande vikt av 36 $\pm 1.1 \mathrm{~kg}$, och med ett testikelomfång av $23.0 \pm 0.5$ $\mathrm{cm}$, vid början av studien (september) hölls på naturligt bete. Levande vikt och testikelomfång registrerades varje månad under studien. På femton baggar togs blod- och spermaprov en gång $i$ månaden från januari till december. I blodproverna analyserades testosteron och tyroxin och spermaproverna under- söktes morfologiskt med avseende på spermiedefekter. Under studien ökade djuren i medeltal $18 \mathrm{~kg}$ (ca 50\%) men under hösten sjönk levandevikten. Maximal testikelstorlek registrerades i slutet av sommaren $(31.1 \pm 0.4 \mathrm{~cm} ; \mathrm{p}<0.01)$ varefter den sjönk och var låg till den började öka igen på våren. Testikelomfånget var $16 \%$ mindre under vintern jämfört med sommaren. Den lägsta andelen spermiedefekter registrerades på hösten. De lägsta tyroxinkoncentrationerna registrerades under sen sommar/tidig höst när testosteron var som högst. De högsta tyroxinkoncentrationerna uppmättes från sen höst, samtidigt som testikelomfånget minskade, till tidig sommar. Studien visar att Corriedale baggar i ett extensivt Latinamerikanskt uppfödningssystem visar i stort sett samma säsongsmässiga förändringar $i$ fortplantningssystemet som andra fårraser där den årliga fortplantningscykeln styrs av förändringar i dagsljuslängden.

(Received February 12, 1996; accepted November 28, 1996).

Reprints may be obtained from: Raquel Pérez, Dept. of Anim. Anatomy and Physiology, Faculty of Agronomy, University of Uruguay, Montevideo, Uruguay. E-mail: raquelpl@ata.edu.uy, fax: +598-2 393004, tel: +5982341564 . 
